\title{
Work Organization and Risks of Illness in the Professional Practice of Doctors
}

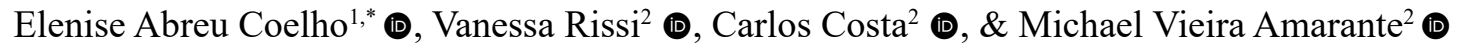 \\ ${ }^{1}$ Universidade Federal de Santa Maria, Santa Maria, RS, Brasil \\ ${ }^{2}$ Faculdade Meridional, Passo Fundo, RS, Brasil
}

\begin{abstract}
The work context is a risk factor for the illness of many professionals, among which the medical profession is highlighted. Thus, this study aimed to identify the risks of illness related to the work context of doctors, in the light of Psychodynamics at Work. One hundred and two professionals participated, who responded to the Work Context Assessment Scales, Indicators of Pleasure and Suffering at Work and Work-Related Damage. The results, based on descriptive and inferential statistics, demonstrated a moderate risk of illness related to the work context, professional exhaustion and physical damage. Work organization was strongly associated with "professional burnout" and "lack of recognition". It is concluded, therefore, that there is a need for greater attention to the organization of work by the medical profession.
\end{abstract}

KEYWORDS: Work organization, Doctors, Risks of illness

\section{Organização do Trabalho e Riscos de Adoecimento no Exercício Profissional dos Médicos}

\begin{abstract}
RESUMO - O contexto de trabalho é fator de risco para o adoecimento de muitos profissionais, dentre estes ganha destaque a classe médica. Assim, este estudo objetivou identificar os riscos de adoecimento relativos ao contexto de trabalho de médicos, a luz da Psicodinâmica do Trabalho. Participaram 102 profissionais, que responderam às Escalas de Avaliação do Contexto de Trabalho, Indicadores de Prazer e Sofrimento no Trabalho e Danos Relacionados ao Trabalho. Os resultados, a partir de estatística descritiva e inferencial, demonstraram risco moderado de adoecimento relacionado ao contexto de trabalho, esgotamento profissional e danos físicos. Associou-se fortemente a organização do trabalho com "esgotamento profissional" e "falta de reconhecimento". Conclui-se, assim, que ocorre a necessidade de maior atenção à organização do trabalho da classe médica.
\end{abstract}

PALAVRAS-CHAVE: Organização do trabalho, Médicos, Riscos de adoecimento

\section{INTRODUCTION}

Studies that investigate the aspects involved in the relationship between man versus work and that predispose workers to illness, or that, in the midst of harmful contexts, act in the preservation of health are not recent (Augusto et al., 2014; Martins \& Mendes, 2012; Máximo et al., 2014; Merlo \& Lapis, 2007). However, research that includes the subjective dimension of work as a potential risk factor for workers' health dates back only to the 1980s, when theoretical and methodological references, especially the Psychodynamics of Work and the Ergological perspective, adopted a dynamic analysis that has based on the nature of the activity, real work (Ruiz \& Araújo, 2012).

*E-mail: elenise.ac@gmail.com

- Submetido: 16/10/2018; Aceito: 17/09/2020. 
From then on, in order to assess the risks of illness of the worker, the subjective dimension of work is considered beyond the objective conditions, such as the physical, chemical and biological aspects (Mendes \& Ferreira, 2007). This includes processes that escape institutional prescriptions and enter the managerial scope of the worker himself in relation to his activity (Ruiz \& Araújo, 2012)

In this sense, based on the Psychodynamics of Work and in theoretical harmony with the Activity Ergonomics, Mendes and Ferreira (2007) established the following variables as risk factors for illness at work: a) the work context, constituted by the organization of work, socio-professional conditions and relationships; b) the demands caused by the context, in terms of physical, cognitive and affective costs; c) aspects related to experiences of pleasure (professional fulfillment and freedom of expression) and suffering at work (professional exhaustion and lack of recognition); and, still, d) the physical and psychosocial damages caused by the demands and experiences of the work.

It is emphasized that the organization of work is an aspect of the subjective dimension of work, considered for Work Psychodynamics, as crucial for the understanding of workers' health and illness processes (Augusto et al., 2014; Rancan \& Giongo, 2016). Since it corresponds to the division of labor (prescribed work, mode of production, rhythm, the realization and division of tasks) and the division of men (relational scope of work, hierarchy, power and control relations, autonomy, communication and cooperation) (Dejours \& Abdoucheli, 1994), it deserves to be investigated.

The identification of risk factors for illness has been the objective of research with samples from different professional categories, as it is the case of teachers (García et al., 2016), in which the risks are characterized by high psychological demands, low self-esteem, scarce social support and job insecurity. General service workers working in the health sector (Andrade et al., 2016), showed muscle pain, exhaustion and stress, associated with the lack of support from management. In the area of health, the risk of illness for nurses was the pace of work $(97.6 \%)$, insecurity about working conditions (66.1\%), as well as high emotional demands (65, 2\%) (Jimenez et al., 2017).

Specifically, in relation to medicine, it appears that the researches that relate the medical category to illness at work are still concise in comparison to other professional classes. However, it is necessary to consider the changes undergone by the current medical work, with the commercialization of health services, the influence of the pharmaceutical and aesthetic industry and the new diagnostic and therapeutic technologies, which produced changes in the lifestyle of this professional, loss of autonomy in managing their own work and decreased remuneration (Gracino et al., 2016).
At the international level, special emphasis is placed on aspects related to stress and the development of occupational diseases such as burnout (Ohlander et al., 2015; Somville et al., 2016). An example is the study by Buddeberg-Fischer et al. (2008), who investigated a population of 433 resident physicians, finding high levels of stress related to the number of hours worked per week.

Richter et al. (2014) associate stress and emotional exhaustion in medical work with the increased workload and shifts, with reduced time for rest breaks. From another perspective, in a sample of 88 doctors, Ilic et al. (2017) showed that the perception of freedom at work, social support, the sense of coherence and investments in mental health are negatively related to work wear.

In the Brazilian context, studies emphasize aspects related to experiences of pleasure and suffering, such as constant contact with human fragility that causes intense emotional demands (Barros \& Honório, 2015). Regardless, Lima and Castanha (2011) highlight the loss of patients and treatment with incurable diagnoses that generate feelings of helplessness and suffering.

There are researchers who highlight the configuration of the Brazilian health complex, which differs from other countries by implementing the Unified Health System (SUS). As it has a more preventive focus, it requires a network of professionals prepared to meet individual and collective demands and preventive actions, to the detriment of the diagnosis and treatment of diseases. This generates a mismatch between traditional medical training with a hospital-centered approach and the requirements of the new work organization (Feliciano et al.,2011; Vasconcellos \& Zaniboni, 2011). The excessive pace, work overload and unpredictability of work were also evidenced as risk factors (Honório \& Simões, 2016).

It is also noteworthy that there is a high demand from society in relation to the practical knowledge of medicine, attaching it to a gift, which, on the one hand, converts into recognition, on the other, can generate intense emotional exhaustion considering job responsibilities (Rocha et al., 2015). Added to these factors one may find the issue of self-medication because they are professionals with easy access and the difficulty in seeking help when in situations of illness (Brooks et al., 2011; Andrade \& Dantas, 2015).

Given the potential of work to produce risks of illness and considering the specificities of medical work, studies that emphasize health and disease processes and the work relationships of this category are important, since when producing the collective health, they may be exposed to degradation of their own health (Dias, 2015). Thus, in the light of the concepts of Psychodynamics at Work, this research sought to identify the risks of illness related to the work context of doctors. 


\section{METHOD}

The project related to this research was previously submitted for consideration by the Research Ethics Committee (CEP) of Faculdade Meridional (IMED), according to the resolutions of the Brazilian National Health Council (CNS), n. 466/2012 and no. 510/2016 and remained approved, under opinion no. 2,130,795.

The method adopted was a quantitative, descriptive and cross-sectional design. One hundred and two physicians participated, recruited by a non-probabilistic sampling plan and accessibility. The inclusion criteria were considered: being a doctor, of any specialty recognized by the Brazilian Federal Council of Medicine (CFM), having a job in public and/ or private health services and working in the State of Rio Grande do Sul. Freelancer Doctors with exclusive practice in the office were excluded, as well as those who were away from work for any reason, or who did not complete the entire instrument of research.

Of the study participants, $52.2 \%$ are male, $70.4 \%$ are between 25 and 40 years old, $41.6 \%$ are married, and
$54.5 \%$ have the highest educational level at Specialization. Regarding professional performance, $46 \%$ have worked for up to five years and $17 \%$ of the sample has worked in medicine for more than 20 years. As for working hours, $75 \%$ work more than 40 hours a week, and the $33.3 \%$ monthly income range is above $\mathrm{R} \$ 20,000.00$, while $28 \%$ receives between R $\$ 5,000.00$ and $\mathrm{R} \$ 10,000.00$.

The instruments used were the Work Context Assessment Scale (EACT), Work Pleasure and Suffering Scale (EIPST) and the Work Related Damage Scale (EADRT), which make up the Work Inventory and Risks of Illness (ITRA), built and validated by Mendes and Ferreira (2007). The scales are of the Likert type, interdependent, with approximately thirty statements that assess the interrelationship between work and the modes of subjectivation, based on how the worker experiences his work context and the consequences on his health. Each scale is made up of specific dimensions, as described in Figure 1.

\begin{tabular}{|c|c|c|c|}
\hline Scale & Description & Dimensions & $(\alpha)$ \\
\hline \multirow{3}{*}{ EACT } & \multirow{3}{*}{$\begin{array}{l}\text { It evaluates the subjective aspects (autonomy, power relations, } \\
\text { production rhythm, among others), social relations and physical } \\
\text { structure at work. }\end{array}$} & Organization of work & 0,805 \\
\hline & & Socio-professional relations & 0,900 \\
\hline & & Work conditions & 0,943 \\
\hline \multirow{4}{*}{ EIPST } & \multirow{4}{*}{$\begin{array}{l}\text { Evaluates experiences related to feelings of pleasure and } \\
\text { suffering at work. }\end{array}$} & Freedom of expression & 0,911 \\
\hline & & Professional achievement & 0,928 \\
\hline & & Professional Burnout & 0,919 \\
\hline & & Lack of recognition & 0,933 \\
\hline \multirow{3}{*}{ EADRT } & \multirow{3}{*}{$\begin{array}{l}\text { Evaluates the physical and psychosocial damage caused by } \\
\text { work. }\end{array}$} & Physical damage & 0,866 \\
\hline & & Psychological damage & 0,940 \\
\hline & & Social harm & 0,859 \\
\hline
\end{tabular}

Figure 1. Description of the scales used in the study and psychometric indices

In the interpretation of the instrument, the risk of falling ill occurs by calculating the averages of the factors that make up the dimensions, classifying them into serious, critical, moderate or satisfactory levels. Its analysis must be made from three levels that consider the midpoint and standard deviations from it. The reference values for interpreting the results are shown in Table 1. It is worth noting that, for the analysis of the Work-Related Damage Assessment Scale (EADRT), a moderate assessment already means becoming ill (Mendes \&Ferreira, 2007).

Data collection was carried out in online formats (through the Google Docs platform) and printed. Invitation messages were sent to physicians via e-mail, where they could access information about the purposes, criteria for inclusion in the study, the guarantee of the confidentiality of their identities and the link to access the Informed Consent
Form (ICF) for registration of their consent. Subsequently, they were directed to the page with the instruments.

The printed questionnaires were provided in person by the researchers by appointment, both for delivery and withdrawal. Some doctors took questionnaires to their colleagues, returning them, filled in, with theirs. In the case of the printed questionnaires, there were two copies of the informed consent form, one of which was held by the participant and the other by the researchers.

The data were analyzed using descriptive statistics (frequency distribution, means and standard deviation) to characterize the sample and analyze the means of the factors. The normality test (Shapiro-Wilk) was used for the research dimensions: work organization, lack of recognition, emotional exhaustion, physical damage, social damage and psychological damage. Due to not being characterized 
as a normal distribution, Spearman's nonparametric test was applied to identify the associations between work organization and the other variables that characterize the risks of illness. All analyses were performed using the SPSS Statistics software (v. 23, IBM SPSS, Chicago, IL).
About 400 e-mails were sent, obtaining 16 responses online, with a total response rate of approximately $10.9 \%$. The printed questionnaires were delivered to 190 doctors, of which 86 were returned ( $45.3 \%$ return rate). Data collection took place between August and October 2017.

Table 1

Reference values for the interpretation of the scale results

\begin{tabular}{lcc}
\hline \multicolumn{1}{c}{ Scale } & Reference values & Level \\
\hline Scale Assessment Scale of Work & Above 3.7 & Serious \\
& Between 2.3 and 3.69 & Critical \\
\hline Scale of Pleasure Indicators and Suffering & Below 2.29 & Satisfactory \\
at Work* & Above 3.7 & Critical \\
\hline & Between 2.3 and 3.69 & Serious \\
Damage Assessment Scale Work-related & Below 2.29 occupational diseases \\
& Above 4.1 & Serious \\
& Between 3.1 and 4.0 & Critical \\
\hline
\end{tabular}

Source: Prepared by the authors based on the instrument of Mendes and Ferreira (2007). *For factors related to experiences of suffering, the levels of assessment are reversed.

\section{RESULTS}

The descriptive results are presented from the calculation of the averages, which classifies the dimensions of each of the scales in terms of severity indices related to the work situation. These data represent the situation of suffering or illness at work in the study group (Table 2).

It is observed that, in relation to the work context, all factors indicate a moderate critical risk for illness, with the highest average attributed to the work organization factor $\left(\mathrm{x}^{-}=3.31 ; \mathrm{SD}=0.61\right)$, a variable that represents the subjective aspects implicit in the work context (sense of autonomy, power relations, rhythm, pressure, among others). In the analysis of the EIPST, it appears that the participants show high levels of pleasure at work, including the average attributed to the lack of recognition $\left(\mathrm{x}^{-}=1.62\right.$; $\mathrm{SD}=1.48$ ), which, although being part of the suffering experiences, obtained a satisfactory evaluation. However, the emotional exhaustion factor indicates a critical level for illness at work $\left(\mathrm{x}^{-}=2.93 ; \mathrm{SD}=1.27\right)$. As for the analysis of the EADRT factors, the three dimensions of the scale showed a more positive evaluation, which means a bearable state in terms of damage, whether it is physical, social and psychological.

In general, the descriptive results demonstrate that the physicians participating in the study show a risk of critical illness related to variables in the work context and professional exhaustion. Spearman's correlation test was used to identify associations between the factors of work organization and physical damage, psychological damage, social damage, lack of recognition and professional exhaustion that characterize the risks of illness at work (Table 3).

The results indicate significant correlation rates between the six factors. Since the focus of the investigation is the organization of work, which involves aspects intrinsic to the context, it is observed that it is associated with the other variables that characterize the risks of illness. The higher correlation rates between the factors professional burnout and lack of recognition $(r=0.77, p<0.01)$ and social and psychological damages $(r=0.85, p<0.01)$, demonstrate the impact of subjective dimensions of work in the risk of suffering and illness of the worker. 
Table 2

Descriptive statistics of the means attributed to the dimensions of the scales

\begin{tabular}{lcccc}
\hline \multicolumn{1}{c}{ Variable } & Minimum & Maximum & Average $(\bar{x})$ & Standard deviation (SD) \\
\hline EACT & & & & \\
\hline Organization of work & 1,6 & 4,7 & 2,31 & 0,61 \\
\hline Socio-professional relations & 1,0 & 4,1 & 2,46 & 0,67 \\
\hline Work conditions & 1,0 & 5,4 & 2,32 & 1,81 \\
\hline EIPST & & & & \\
\hline Freedom of expression & 0,3 & 6,0 & 4,53 & 1,28 \\
\hline Professional achievement & 0,7 & 6,0 & 4,63 & 1,57 \\
\hline Emotional exhaustion & 0,0 & 6,0 & 2,93 & 1,48 \\
\hline Lack of recognition & 0,0 & 5,5 & 1,62 & \\
\hline EADRT & & & & 1,79 \\
\hline Physical damage & 0,0 & 4,9 & 1,27 & 1,19 \\
\hline Social harm & 0,0 & 5,3 & 1,03 & 1,34 \\
\hline Psychological damage & 0,0 & 6,0 & & \\
\hline
\end{tabular}

Table 3

Correlation values (Spearman) and significance levels of associations between factors

\begin{tabular}{|c|c|c|c|c|c|c|}
\hline Variable & 1 & 2 & 3 & 4 & 5 & 6 \\
\hline 1 Work organization & 1 & & & & & \\
\hline 2 Lack of recognition & $0.547 * *$ & 1 & & & & \\
\hline 3 Emotional exhaustion & $0.507 * *$ & $0.768 * *$ & 1 & & & \\
\hline 4 Physical damage & $0.473 * *$ & $0.452 * *$ & $0.604 * *$ & 1 & & \\
\hline 5 Social damage & $0.456 * *$ & $0.616^{* *}$ & $0.604 * *$ & $0.653 * *$ & 1 & \\
\hline 6 Psychological damage & $0.407^{* *}$ & $0.635^{* *}$ & $0.642 * *$ & $0.596^{* *}$ & $0.845^{* *}$ & 1 \\
\hline
\end{tabular}

$* * \mathrm{p}<0.01$

\section{DISCUSSION}

Regarding the factors of the Work Context Scale, all had scores that characterize a level of moderate to critical for the risk of illness, especially the factor "work organization". In the literature on the theme, this scenario of risk work context corroborates the findings of Farias and Araújo (2017), who, when reviewing studies on Brazilian hospital management, found the presence of conflicts in socio-professional relationships, difficulties in communication and little clarity in defining work processes. Along the same line, Dourado and Honório (2019), in their research with oncologists who work in clinics and hospitals, also point out elements of work organization as triggers of suffering, especially the intense functional rhythm and the demand for results.

The model of management and organization of the work context to which Brazilian doctors are exposed results from the strong demands of productivity, which, in generating an impasse between the work to be performed by professionals and the objective work conditions, also compromise the quality of the work service provided (Feliciano et al., 2011; Shimizu \& Carvalho, 2012).

In the analysis of the EIPST, it was observed that in the dimension "pleasure", the participants attributed high averages to the factors "professional achievement" and "freedom of expression". These data confirm the evidence that the sampled doctors feel professionally accomplished, which includes appreciation, personal gratification and identification with the tasks. Nevertheless, the "lack of recognition at work" factor, which is located in the "suffering" dimension, obtained a lower average, confirming the perception of recognition. This is an important finding as the recognition makes it possible to redefine experiences of suffering at work (Dejours, 2004). Furthermore, it is a fundamental aspect in the health and work relationship, since it constitutes the worker's identity and allows for the experiences of pleasure and self-realization (Bendassoli, 2012). There are authors who also argue that the relationship 
between recognition, work and health offers important elements to think about the worker's health area (Silva et al., 2015). Such positive experiences of medical workers are usually associated with the recognition provided by the doctor-patient relationship (Barros \& Honório, 2015; Lima \& Castanha, 2011).

However, the variable "professional exhaustion" obtained a moderate critical risk score and confirm the findings of literature (Barbosa et al., 2017), highlighting an American study that compared the population in general and that of medical professionals and indicated that the latter presents a higher risk of exhaustion (Shanafelt et al., 2012).

As for the peculiarities of medical work that lead to situations of exhaustion, Marques et al. (2020), when investigating doctors who work in urgent and emergency services, showed feelings of exhaustion and anguish due to stress arising from work, fear and fear of not being able to do what they need to in the time available, in addition to the remuneration not in line with expectations. Along the same lines, Souza and Mourão (2018) also found the lack of control, conflicting professional relationships, work overload, chronic sleep deprivation and increased pressure for managerial responsibility as factors favoring exhaustion.

There was a significant positive association $(\mathrm{P}<0.01)$ between work organization and social and psychological damage, professional exhaustion and lack of recognition, validated by Mendes (1995), who refers to work organization as a central aspect of the process of working, capable of producing pleasure, but also of generating illness. Accordingly, Moreira et al. (2018) reviewed the studies on the prevalence of burnout syndrome among doctors, and in general, identified factors that favor occupational illness related to work organization and environment structure, highlighting aspects such as internal conflicts, poor communication, lack of certainty about the future concerning employment contracts and stress management.

Analyzing in detail the studies contemplated in this review (Moreira et al., 2018), it is observed that each medical specialty is associated with different factors that promote and protect against stress, both related to the characteristics of the work organization and to the work itself. Physicians working in the Intensive Care Units (ICU) reported high levels of stress related to assisting serious illnesses and decision making in cases of terminal phase, conflicts between colleagues and with family members of patients. On the other hand, the division of responsibilities and the distribution of tasks aimed at optimizing the work of the ICU proved to be mitigating factors, as highlighted in the research by Teixeira et al. (2013) and Barbosa et al. (2012).

For the specialties Emergency Physicians (ME) and Family Physicians (MF), in turn, Cubillo et al. (2012) and Galván et al. (2014), indicate that high stressors and low involvement with work, scarcity of resources, discrepancies between expectations and the work actually performed, dissatisfaction with remuneration and career prospects are reported as stress drivers.

Considering the variety of specialties and areas of activity, doctors are exposed to various types of health risks in the exercise of their work, including chemical, biological and physical in the handling of equipment and especially of a psychosocial nature. The high values found in this study in the correlation between variables that correspond to subjective dimensions, such as psychological and social damage, lack of recognition and professional exhaustion, demonstrate the need for attention to the doctor's work organization and studies that investigate the singularities of the healthcare process and work of these professionals in its multiple forms (Dias, 2015).

The results observed in this study do not suggest serious health problems in the researched public. However, the factors of work organization and professional burnout deserve special attention, since they obtained expressive rates of illness. In-depth analysis of these dimensions can reveal critical points in the workplace, which, because they cause discomfort, need improvements to avoid further damage.

\section{FINAL CONSIDERATIONS}

Psychosocial risk factors permeate the work context of all professional categories. Specifically, with respect to doctors, the characteristics of the work organization that favor occupational illness were little known.

Thus, the study fulfilled its objective of verifying the existence of an association between the organization of work and the risks of suffering and illness in the medical professional practice. The analysis of the averages points to moderate and critical risks of illness, regarding the dimensions of the work context and professional exhaustion. No physical, psychological and social damage indexes were found. Corroborating data from the existing literature, the doctors in the study showed high scores for pleasure at work, provided by the feelings of professional achievement, freedom of expression and recognition.

Work organization was the highest risk factor among the surveyed dimensions, revealing the potential to produce health or illness, depending on the management modes of the work context. Its relationship with the other risk factors was found, producing subsidies to deepen the analysis about the importance of the subjective aspects inherent to the work context and its potential to generate damage to the health of workers.

The main limitation of the study is the number of participants, which is not representative of the population of doctors in Rio Grande do Sul, therefore, it does not 
allow inferences and generalizations to be made. For future research, it is suggested to expand the sample, also considering the relationship of risk factors with functional variables, such as specialty, workload and sectors, since the literature points out some specialties with a higher prevalence of occupational disease.

Since the exercise of professional activity contributes to the promotion and preservation of health, as part of the subjects' own identity, understanding how workers experience their work process is of fundamental importance. In this sense, specifically in relation to the management of current health services, the research provides information to encourage the creation of effective prevention and intervention strategies, aimed at promoting the health of doctors in their various contexts of insertion, based on changes in organization of work.

\section{REFERENCES}

Andrade, M. O., Cunha, V. S., Lins, W. M. S., Yung, F. R., Abdon, J. A. S., \& Souza, E. M. (2016). Saúde ocupacional e riscos psicossociais de trabalhadores da limpeza de instituições de ensino superior: Um estudo qualitativo em Brasília, DF. Tempus, Acta de Saúde Coletiva, 10(1), 143-156. http://dx.doi. org/10.18569/tempus.v10i1.1859

Andrade, A. G. O., \& Dantas, R. A. A. (2015). Transtornos mentais e do comportamento relacionados ao trabalho em médicos anestesiologistas. Revista Brasileira de Anestesiologia, 65(6), 504-510. http://dx.doi.org/10.1016/j.bjan.2013.03.021

Augusto, F. M. M., Freitas, L. G., \& Mendes, A. M. (2014). Experiences of pleasure and suffering in the work of a professional public research. Psicologia em Revista, 20(1), 34-55. https://doi.org/10.33448/rsd-v10i2.12668

Barbosa, F. T., Eloi, R. J, Santos, L. M., Leão, B. A, Lima, F. J. de, \& Sousa-Rodrigues, C. F. de. (2017). Correlação entre a carga horária semanal de trabalho com a síndrome de burnout entre os médicos anestesiologistas de Maceió-AL. Revista Brasileira de Anestesiologia, 67(2), 115-121. https://doi.org/10.1016/j. bjane.2015.06.001

Barbosa F. T., Leão B. A., Tavares G. M., \& Santos J. G. (2012). Burnout syndrome and weekly workload of on-call physicians: Cross-sectional study. São Paulo Medical Journal, 130(5), 282-8. https://doi.org/10.1590/S1516-31802012000500003

Barros, N. M. G. C., \& Honório, L. C. (2015). Riscos de adoecimento no trabalho de médicos e enfermeiros em um hospital regional mato-grossense. Revista de Gestão (REGE), 22(1), 21-39. https://doi.org/10.5700/rege549

Bendassolli, P. F. (2012). Reconhecimento no trabalho: Perspectivas e questões contemporâneas. Psicologia em Estudo, 17(1), 37-46. https://doi.org/10.1590/S1413-73722012000100005

Brooks, S. K., Gerada, C., \& Chalder, T. (2011). Review of literature on the mental health of doctors: Are specialist services needed? Journal of Mental Health, 20(2), 146-156. https://doi.org/10.3 109/09638237.2010.541300

Buddeberg-Fischer, B., Klaghofer, R., Stamm, M., Siegrist, J., \&Buddeberg, C. (2008). Work stress and reduced health in young physicians: Prospective evidence from Swiss residents. International Archives of Occupational and Environmental Health, 82(1), 31-38. 10.1007/s00420-008-0303-7

Cubillo A. C., Guevara J. C., Bravo J. J., Riguera M. J., Castro M. L., \& Sanz A. G. (2012). Evolución del burnout y variables asociadas en los médicos de atención primaria. Atención Primaria, 44(9), 532-39. https://doi.org/10.1016/j. aprim.2010.05.021

Dejours, C. (2004). Subjetividade, trabalho e ação. Revista Produção, 14(3), 027-034. https://doi.org/10.1590/S010365132004000300004

Dejours, C., \& Abdoucheli, E. (1994). Desejo ou motivação? A interrogação psicanalítica do trabalho. In C. Dejours, E. Abdoucheli, \& C. Jayet (Eds.). Psicodinâmica do trabalho: Contribuições da escola dejourina à análise da relação prazer, sofrimento e trabalho. Atlas.
Dias, E. C. (2015). Condições de trabalho e saúde dos médicos: Uma questão negligenciada e um desafio para a Associação Nacional de Medicina do Trabalho. Revista Brasileira de Medicina do Trabalho, 13(2), 60-68. http://files.bvs.br/ upload/S/1679-4435/2015/v13n2/a5229.pdf

Dourado, M. S., \& Honório, L. C. (2019). Otrabalho de médicos oncologistas: Evidências psicodinâmicas de prazer e sofrimento ocupacional. RGO - Revista Gestão Organizacional, 12(2), 3-23. http://dx.doi.org/10.22277/rgo.v12i2.4321

Farias, A., \& Araújo, F. O. (2017). Gestão hospitalar no Brasil: Revisão da literatura visando ao aprimoramento das práticas administrativas em hospitais. Ciência e Saúde Coletiva, 22(6), 1895-1904. https://doi.org/10.1590/141381232017226.26432016

Feliciano, K. V. O., Kovacs, M. H., \& Sarinho, S. W. (2011). Burnout entre médicos da Saúde da Família: Os desafios da transformação do trabalho. Ciência \& Saúde Coletiva, 16(8), 3373-3382. https://doi.org/10.1590/S1413-81232011000900004

García, M. M., Iglesias, S., Saletab, M., \& Romay, J. (2016). Riesgos psicosociales en el profesorado de enseñanza universitaria: Diagnóstico y prevención. Journal of Work and Organizational Psychology, 32(3), 173-178. http://dx.doi.org/10.1016/j. rpto.2016.07.001

Galván M. E., Vasallo J. C., Rodríguez S. P., Otero P., Montonati M. M., Cardigni G., Buamscha, D. G., Rufach, D., Santos, S., Moreno, R. P., \&Sarli, M. (2014). Síndrome de desgaste profesional (burnout) en médicos de unidades de cuidados intensivos pediátricos en la Argentina. Revista de la Sociedad Boliviana de Pediatría, 53(1), 29-36. http:// www.scielo.org.bo/scielo.php?script=sci_arttext\&pid $=\mathrm{S} 1024-06752014000100008$

Gracino, M. E., Zitta, A. L. L., Mangili, O. C., e Massuda, E. M. (2016). A saúde física e mental do profissional médico: Uma revisão sistemática. Saúde Debate,40(110), 244-263. https:// doi.org/10.1590/0103-1104201611019

Honório, L. C., \& Simões, D. A. P. (2016, 31 de outubro - 01 de novembro). Prazer e sofrimento no trabalho de médicos oncologistas: Estudo em uma clínica hospitalar mineira [apresentação em conferência]. Simpósio de Excelência e Gestão e Tecnologia(SEGET), Rio de Janeiro, RJ, Brasil. https://www.aedb.br/seget/arquivos/artigos16/23024230.pdf

Ilic, I., Arandjelovic, M., Jovanovic, J., \&Nesic, M. (2017). Relationships of work-related psychosocial risks, stress, individual factors and burnout - Questionnaire survey among emergency physicians and nurses. Medycyna Pracy, 68(2), 167-178. https://doi.org/10.13075/mp.5893.00516

Jimenez, C. A., Orozco, M. M., \& Caliz, N. E. (2017). Factores de riesgos psicosociales en auxiliares de enfermería de un hospital de la red pública en la ciudad de Bogotá, Colombia. Revista U.D.C.A Actualidad \& Divulgación Cientifica, 20(1), 23-32. http://www.scielo.org.co/pdf/rudca/v20n1/v20n1a04.pdf

Lima, J. H. V., Jr., \& Castanha, A. L. B. (2011, 4-7 de setembro). $O$ trabalhador médico: Prazer e dor como oficio [apresentação 
em conferência]. Encontro da ANPAD, Rio de Janeiro, RJ, Brasil. http://www.anpad.org.br/admin/pdf/GPR1767.pdf

Marques, L. R., Honório, L. C., \& Marques, A. L. (2020). Burnout no trabalho do médico: $\mathrm{O}$ caso dos profissionais que atuam no serviço de atendimento de urgência e emergência na cidade de Belo Horizonte-MG. Revista Gestão \& Tecnologia, 20(1), 190-214. 10.20397/2177-6652/2020.v20i1.1623

Martins, S. R., \& Mendes, A. M. (2012). Espaço coletivo de discussão: A clínica psicodinâmica do trabalho como ação de resistência. Collective space for discussion: the clinical psychodynamic of work as an act of resistance. Revista Psicologia: Organizações e Trabalho, 12(2), 171-184. http://pepsic.bvsalud.org/scielo.php?script=sci_arttext\&pid $=\mathrm{S} 1984-66572012000200004$

Máximo, T. A. C. O., Araújo, A. J. S., \& Zambroni-de-Souza, P. C. (2014). Vivências de sofrimento e prazer no trabalho de gerentes de banco. Psicologia: Ciência e Profissão,34(1), 96-111. https://doi.org/10.1590/S1414-98932014000100008

Mendes, A. M. B. (1995). Aspectos Psicodinâmicos da relação homem-trabalho: as contribuições de C. Dejours. Psicologia Ciência e Profissão, 15(1-3), 34-38.

Mendes, A. M., \& Ferreira, M. C. (2007). Inventário sobre trabalho e riscos de adoecimento (ITRA): Instrumento auxiliar de diagnóstico de indicadores críticos no trabalho. In A. M. Mendes (Ed.). Psicodinâmica do trabalho: Teoria, método e pesquisas (pp. 111-126). Casa do Psicólogo.

Merlo, A. R. C., \& Lapis, N. L. (2007). A saúde e os processos de trabalho no capitalismo: Reflexões na interface da psicodinâmica do trabalho e da sociologia do trabalho. Psicologia \& Sociedade, 19(1), 61-68. https://doi.org/10.1590/ S0102-71822007000100009

Moreira, H. de A., Souza, K. N. de, \& Yamaguchi, M. U. (2018). Síndrome de Burnout em médicos: Uma revisão sistemática. Revista Brasileira de Saúde Ocupacional, 43(e3), 1-11. https:// doi.org/10.1590/2317-6369000013316

Ohlander, J., Weigl, M., Petru, R., Angerer, P., \& Radon, K. (2015). Working conditions and effort-reward imbalance of German physicians in Sweden respective Germany: A comparative study. International Archives of Occupational and Environmental Health, 88(4), 511-519. doi 10.1007/ s00420-014-0978-x

Rancan, M., \&Giongo, C. R. (2016). "Eles determinam, nós produzimos": Subjetividades capturadas pelo trabalho metalomecânico. Psicologia \& Sociedade, 28(1), 135-144. https://doi.org/10.1590/1807-03102015v28n1p135
Richter, A., Kostova, P., Baur, X., \& Wegner, R. (2014). Less work: More burnout? A comparison of working conditions and the risk of burnout by German physicians before and after the implementation of the EU Working Time Directive. International Archives of Occupational and Environmental, 87(2), 205-215. doi: 10.1007/s00420-013-0849-x

Rocha, A. P. F., Souza, K. R., \& Teixeira, L. R. (2015). A saúde e o trabalho de médicos de UTI neonatal: Um estudo em hospital público no Rio de Janeiro. Revista de Saúde Coletiva, 25(3), 843-862. https://doi.org/10.1590/S0103-73312015000300009

Ruiz, V. S., \& Araújo, A. L. L. (2012). Saúde e segurança e a subjetividade no trabalho: Os riscos psicossociais. Revista Brasileira de Saúde Ocupacional, 37(125), 170-180. https:// doi.org/10.1590/S0303-76572012000100020

Shimizu, H. E., \& Carvalho, D. A. C., Jr. (2012). The working process in the Family Health Strategy and its repercussions on the health-disease process. Ciência\&SaúdeColetiva, 17(9), 24052414. https://doi.org/10.1590/S1413-81232012000900021

Shanafelt T. D., Boone S., Tan L., Dyrbye, L. N., Sotile, W., Satele, D., West, C. P., Sloan, J., \&Oreskovich, M. R (2012). Burnout and satisfaction with work-life balance among us physicians relative to the general us population. Arch Intern Med., 172(18), 1377-85. doi:10.1001/archinternmed.2012.3199

Silva, R. V. S., Deusdedit-Júnior, M., \& Batista, M. A. (2015). A relação entre reconhecimento, trabalho e saúde sob o olhar da Psicodinâmica do Trabalho e da Clínica da Atividade: Debates em psicologia do trabalho.Gerais: Revista Interinstitucional de Psicologia, 8(2), 415-427. http://pepsic.bvsalud.org/scielo. php?script=sci_arttext\&pid=S1983-82202015000300010

Souza, A. R. C., \& Mourão, J. I. B. (2018). Burnout em anestesiologia. Revista Brasileira de Anestesiologia, 68(5), 507-517.https://doi.org/10.1016/j.bjan.2018.04.002

Somville, F. J., Gucht, V., \&Maes, S. (2016). The impact of occupational hazards and traumatic events among Belgian emergency physicians. Nutrition and Physical Activity, 24(59), 1-10. doi: 10.1186/s13049-016-0249-9

Teixeira C., Ribeiro O., Fonseca A. M., \& Carvalho A. S. (2013). Burnout in intensive care units - A consideration of the possible prevalence and frequency of new risk factors: a descriptive correlational multicenter study. BMC Anesthesiology, 13(1), 38. doi:10.1186/1471-2253-13-38

Vasconcellos, F. G. A., \&Zaniboni, M. R. G. (2011). Difficulties of medical working at the family health program. Ciência\&SaúdeColetiva, 16(Supl. 1), 1494-1504. https://doi. org/10.1590/S1413-81232011000700085 